\title{
A BEFOGADÓ NEMZETI TÁMOGATÁS KATONAI LOGISZTIKAI KÉPESSÉGEIT BEFOLYÁSOLÓ GLOBÁLIS TRENDEK
}

DOI: $\underline{10.35926 / \mathrm{HSZ} .2020 .4 .9}$

ÖSSZEFOGLALÓ: A NATO kollektív védelmi rendszerének egyik meghatározó eleme a befogadó nemzeti támogatás, mely katonai feladatainak legnagyobb részét a logisztikai rendszer látja el. A nemzeti és szövetségi szinten egyaránt felgyorsult haderőfejlesztés célja a hiteles, dinamikus, ellenállóképes és a jövő kihivásainak megfelelö, elrettentő és támogató erő kialakítása. Egy további, átfogó vizsgálat megalapozása érdekében jelen írásban arra keresi a választ a szerzö, hogy melyek a befogadó nemzeti támogatás katonai feladataihoz szükséges legfontosabb logisztikai képességek, mik a kialakításukat befolyásoló tényezők és hosszú távú trendek.

KULCSSZAVAK: befogadó nemzeti támogatás, logisztika, képességfejlesztés

„A jövő háborúira nem lehet pusztán a jelenkori tapasztalatokra építve felkészülni, igy különös jelentösége van annak, hogy időben felismerjük a változások irányait."”

\section{BEVEZETÉS}

A NATO 2014-től visszatért a megalakulásától a hidegháború befejezéséig folytatott kollektív védelmi (területvédelmi) stratégiájához, amit a megváltozott nemzetközi biztonsági környezet, a Krím annektálása, az elhúzódó kelet-ukrajnai konfliktus, a hibrid fenyegetés megjelenése és részben a 2015-ös migrációs válság váltott ki.

Noha jelenleg Magyarországot a hagyományos fegyverekkel végrehajtott támadás veszélye elenyésző mértékben fenyegeti, a képességfejlesztésben az országvédelem markánsan jelenik meg, míg a müveleti alkalmazásban a humanitárius és a katonai válságkezelö müveletek mutatkoznak nagyobb súllyal.

Hazánk fegyveres védelmét egyrészt a nemzeti haderő, másrészt a NATO kollektív védelmi rendszere garantálja, melynek meghatározó eleme a befogadó nemzeti támogatás (BNT). A közremüködő polgári hatóságokkal, civil szervezetekkel, kormányzati és nem kormányzati, valamint nemzetközi szervezetekkel együttmüködö BNT feladatrendszerének jelentős része a katonai logisztikát érinti. ${ }^{2}$

\footnotetext{
Magyarország Nemzeti Katonai Stratégiája, 2012. Előszó. https://www.kormany.hu/download/a/40/00000/nemzeti_katonai_strategia.pdf (Letöltés időpontja: 2020. 03. 29.)

2 Jároscsák Miklós: Katonai logisztika gyakorlata - Áttekintés a befogadó nemzeti támogatás katonai logisztikát érintő igényeiről. Katonai Logisztika, 2003/1., 164-189. http://epa.oszk.hu/02700/02735/00044/pdf/EPA02735 katonai_logisztika_2003_1.pdf(Letöltés időpontja: 2020.03. 29.)
} 
Jelen írásban a biztonsági környezetet meghatározó változások katonai müveletekre és képességfejlesztésre gyakorolt hatásait, következményeit keresem, alapvetően szövetségesi aspektusból. A politikai, társadalmi, technológiai, gazdasági és környezeti változásokat a teljesség igénye nélkül, kizárólag a BNT egyes katonai, elsősorban a szükséges, hiányzó logisztikai képességekre gyakorolt hatásai szempontjából vizsgálom, hogy meghatározzam, melyek a BNT katonai feladatainak ellátásához szükséges legfontosabb logisztikai képességek, valamint milyen tényezők és hosszú távú trendek befolyásolják azok kialakítását.

\section{GLOBÁLIS TÉNYEZŐK³}

A globális politikai környezetet elsődlegesen a jelenlegi szövetségek, nagyhatalmak és feltörekvő államok közötti, a szükülő erőforrások feletti rendelkezés érdekében folytatott játszmák befolyásolják. A hatalmi átrendeződésre törekvés következtében, illetve a fenntartható fejlődéshez szükséges erőforrások megszerzése és megtartása érdekében új irányelvek körvonalazódnak, melyek támogatják új szövetségek létrejöttét, közös képességek kialakítását és fenntartását. Egyre meghatározóbbá válik a nem kormányzati szereplök és a multinacionális vállalatok befolyása a globális biztonsági helyzetre, erősödik a velük való együttmüködés szükségessége.

Az emberi erőforrás faktort a túlnépesedés és az urbanizáció, a térségenként elöregedő vagy éppen túl fiatal, egyes országokban pedig a megosztott társadalom, valamint az egyenlötlenség és egyes társadalmi rétegek fokozódó elégedetlensége jellemzik. Az elégedetlenség, bizalmatlanság és társadalmi megosztottság miatt felértékelődik a nemzeti ellenálló képesség szerepe. A bolygó túlnépesedésének, valamint az egyre gyakoribb és kiterjedtebb természeti katasztrófáknak egyenes következménye az élelem és az ivóvíz növekvő hiánya, a migráció, amelyek humanitárius müveletek végrehajtását indokolják.

A technológia fejlödése hat legmarkánsabban a társadalmakra. Szociális, kulturális és gazdasági hatásai egyéni, közösségi és állami szinten egyaránt érvényesülnek. A csúcstechnológia alkalmazásával egyrészt növelhető a termelékenység és az életszínvonal, másrészt csökkenthető a természeti erőforrások felhasználása. 2023-ra 49 milliárd eszköz fog csatlakozni a világhálóra, ${ }^{4}$ a mesterséges intelligencia, az autonóm rendszerek, $3 \mathrm{D}$ nyomtatás (additív gyártás), robotika, nanotechnológia, biotechnológia, fejlett ember-gép felület alkalmazása beláthatatlan távlatokat nyit.

A környezet- és klímaváltozás hatásainak csökkentése és az alkalmazkodás érdekében előtérbe kerül az alternatív energia alkalmazása, valamint a hibrid technológia széles körü elterjedése várható.

\footnotetext{
Strategic Foresight Analysis 2017 Report. Allied Command Transformation, Norfolk, 2017. https://www.act. nato.int/images/stories/media/doclibrary/171004_sfa_2017_report_hr.pdf (Letöltés időpontja: 2020. 03. 29.)

4 A Cisco szerint ezek lesznek a legjellemzőbb trendek a következő évtizedben. 2019. 12. 30. http://androgeek.hu/ hir/a-cisco-szerint-ezek-lesznek-a-legjellemzobb-trendek-a-kovetkezo-evtizedben (Letöltés időpontja: 2020. 01. 16.)
} 


\section{A JÖVŐ KATONAI KONFLIKTUSAINAK JELLEMZŐI}

A jövő konfliktusai ${ }^{5}$ elhúzódóak, melyekben kis létszámú csapatokat globálisan elszórtan, nagy távolságokban alkalmaznak. A hadviselési tartományok ${ }^{6}$ összemosódnak, kapcsolatuk a polgári információs környezettel szélesedik. A hadászati, műveleti és harcászati szintek továbbra is meghatározók maradnak, de az informatikai rendszereken keresztül erőteljesebben kapcsolódnak, integrálódnak és hálózatokat alkotnak.

Egyrészt az emberi erőforrás hiánya, másrészt az élőerő védelme és a gyorsabb műveleti tempó érdekében elterjed az automatizált, autonóm rendszerek és szenzorok tömeges alkalmazása, illetve lehetővé válik a közvetlen emberi tényezö és kontroll kiiktatása a döntési ciklusból. ${ }^{7}$ A logisztikai lábnyom csökkentése érdekében fokozódik az energiahatékony technológiák alkalmazása.

A Szövetséges Transzformációs Parancsnokság $\left(\mathrm{ACT}^{8}\right)$ ajánlása ${ }^{9}$ szerint a NATO eljövendő műveleteiben történő helytállás érdekében a szövetséges katonai erőnek hitelesnek, hálózatalapúnak, tudatosnak, dinamikusnak és ellenállóképesnek (credible, networked, awared, agile, and resilient) kell lennie.

\section{A HITELES, HÁLÓZATALAPÚ ÉS TUDATOS KÉPESSÉG}

Hitelesnek mondható az az erő, amelynek vezetése, szervezetei és felszerelése képessé teszi az elrettentésre és a bármilyen irányú fenyegetés elleni sikeres fellépésre stratégiai, műveleti és harcászati szinten egyaránt. Szövetségi müveletekben a megfelelő hatékonyság, így a hitelesség kulcsa az interoperabilitás, ennek elérése érdekében kell nemzeti szinten fejleszteni a képességeket, tervezni a kiképzést és a gyakorlatokat.

A saját képességek fejlesztése és alkalmazása többlettervezéssel jár és további költséget generál. A növekvő védelmi kiadások azonban próbára teszik a gazdaságok teljesítőképességét, így növekvő igény mutatkozik a többnemzeti logisztikai megoldásokra, melyekkel a költségek csökkenthetők. A Szövetség vezetési és végrehajtó szintjei, a részt vevő nemzetek és külső szereplők egyaránt függenek egymás képességeitől, melyek fejlesztése érdekében kötött partnerségek és tapasztalatcsere kiterjesztése növelheti a szinergiát.

Az ún. müveleti hálózatok ${ }^{10}$ egy NATO-kezdeményezés a hálózatos együttmüködésre törekvés érdekében, melyhez csatlakozva 35 NATO- és partnernemzet tesz erőfeszítéseket műveleti kommunikációs és információs hálózataik teljes interoperabilitásának elérésére. A 2019 júniusában végrehajtott Exercise Steadfast Cobalt $2019^{11}$ gyakorlat keretében nem-

\footnotetext{
${ }^{5}$ Framework for Future Alliance Operations. Allied Command Transformation, Norfolk, 2018, 11-12. https:// www.act.nato.int/images/stories/media/doclibrary/180514_ffao18-txt.pdf (Letöltés időpontja: 2020. 03. 29.)

${ }^{6}$ Légi, szárazföldi, tengeri, kiber- és ürhadviselési tartományok.

${ }^{7}$ Porkoláb Imre ezredes - Négyesi Imre alezredes: A mesterséges intelligencia alkalmazásának kutatása a haderőben. Honvédségi Szemle, 2019/5., 3-19. https://honvedelem.hu/wp-content/uploads/2019/09/HSz-2019-5_0320_Porkol\%C3\%A1b-Imre_A-mesters\%C3\%A9ges-intelligencia.pdf (Letöltés időpontja: 2020. 03. 31.)

${ }^{8}$ Allied Transformation Command.

${ }^{9}$ Framework for future alliance operations... 19-24.

${ }^{10}$ Federated Mission Network. https://dnbl.ncia.nato.int/FMNPublic/SitePages/Home.aspx (Letöltés időpontja: 2019. 12. 14.)

${ }^{11}$ NATO Agency supports Exercise Steadfast Cobalt 2019. NCI Agency, 27. 07. 2019. https://www.ncia.nato.int/ NewsRoom/Pages/20190726-NATO-Agency-supports-Exercise-Steadfast-Cobalt-2019.aspx (Letöltés időpontja: 2019. 12. 14.)
} 
zeti és többnemzeti alegységek és parancsnokságok közremüködésével tesztelték a NATO Reagáló Erő és a megerősített előretolt jelenlét müveleti információs hálózatainak interoperabilitását.

Politikai, gazdasági és katonai előny elérése érdekében egyaránt várható a polgári lakosság befolyásolására irányuló információs müveletek elterjedése és a kritikus infrastruktúra támadása. A hibrid fenyegetés megjelenésével erősödött a müveleti környezeti jellemzők átfogó ismeretének jelentősége. A vezetési és irányítási rendszereknek ezért a kormányzati és nem kormányzati szervezetek, szerződéses beszállítók és szolgáltatók rendszereihez is kapcsolódniuk kell, hogy a kulturális, etnikai, vallási, diplomáciai, gazdasági adatok megszerzését és feldolgozását biztosítani tudja. A valamennyi hadviselési tartományban folyamatosan fenntartott - és megosztott - „360 fokos” müveleti kép segíthet a befolyásoló müveletek korai felismerésében. A vezetési szintek közötti zavartalan információáramlást a katonai és a polgári kommunikációs hálózatokon széles sávú összeköttetéssel, illetve csökkent kapacitás esetén is biztosítani kell.

\section{AZ ADATALAPÚ KÉPESSÉG}

Az adatok, adatbázisok stratégiai erőforrásnak minősülnek. Az információ gyüjtése, értékelése, adatbázisba rendezése és megosztása a pontos és időbeli döntéshozatal alapja.

A hagyományos rendszerekkel feldolgozhatatlan mennyiségü és méretü, változatos formátumokban (kép, hang, videó stb.) előforduló adatok változási sebessége (pl. szenzorok jelei) és minősége (felderítési információk, illetve közösségi média) hatalmas, folyamatosan változó adatbázist eredményez. ${ }^{12}$ Fejlett technológia nélkül azonban a nagy mennyiségü információ feldolgozása lehetetlen, az elemzést és a további felhasználást mesterséges intelligencia segítheti. A hálózatos alapon müködő gazdasági szektor logisztikai rendszereiben mára egyre elterjedtebb a mesterséges intelligencia alkalmazása, bár a lehetőségek teljes kiaknázása még nem megoldott. ${ }^{13}$

A katonai logisztikai adatbázisokban fegyverrendszerek, gépjármüvek, alkatrészek, élelem, víz stb. mennyiségi adatai mellett a tárolási hely, illetve - alegység vagy eszköz esetén - a készenléti státusz is szerepel, bővítve az adatok mennyiségét. Az egyre komplexebb müveleti környezet egyre több adatot generál, valamennyi hadviselési tartományban nő a müveleti tempó, és ennek következtében a jelenlegi logisztikai rendszerek nem képesek hatékonyan támogatni a jövő müveleteit. ${ }^{14} \mathrm{~A}$ támogatórendszert - a fejlett technológia adta lehetőségek kihasználásával - képessé lehet tenni a duplikációk megszüntetésére, a folyamatok racionalizálására. A haderő számára szükséges személyi állomány, anyagok és eszközök, egészségügyi és katonai müszaki támogatás biztosítása moduláris logisztikai struktúrákat és rugalmas folyamatokat, továbbá egységesített, valamennyi hadviselési tartományra kiterjesztett ellátási rendszert igényel. Minimális követelmény az erőforrások disztribúciós

12 The 4 Characteristics of Big Data. 12. 03. 2019. https://www.bigdataframework.org/four-vs-of-big-data/ (Letöltés időpontja: 2019.01.04.)

13 Artificial intelligence in logistics - A collaborative report by DHL and IBM on implications and use cases for the logistics industry. 2018. https://www.ibm.com/downloads/cas/XOQW7Q0D (Letöltés időpontja: 2019. 01. 04.)

${ }^{14}$ Claudio Constantini: How the US Army Views the Role of AI in Future Military Warfare. 18. 01. 2019. https:/www.linkedin.com/pulse/how-us-army-views-role-ai-future-military-warfare-claudio-costantini/ (Letöltés időpontja: 2019.01.04.) 
hálózatban történő mozgatásának nyomon követése, a döntéstámogatás, a priorizálás és a konfliktusmentesítés.

A fejlett adatbázisok és elemzőeszközök alkalmazásával figyelemmel lehet kísérni a nemzeti és a logisztikai infrastruktúra állapotát, a készletek fogyását, illetve optimalizálhatók és vizualizálhatók a logisztikai folyamatok, felgyorsul a döntéshozatal. Szövetséges szinten - nem töretlenül, de folyamatosan - a koncepció 2006-os elfogadása óta zajlik az ún. müveleti ellátási lánc menedzsment ${ }^{15}$ logisztikai képesség fejlesztése.

A hálózatalapú (logisztikai) képességek kialakítása során kihívásokkal is találkozunk. Az informatikai rendszerek ugrásszerü fejlődésével az avulás felgyorsul, az élettartam csökken, ami megnehezíti az élettartam-menedzsmentet, a váltó rendszer/eszközök beszerzésének tervezését. Szövetségi keretekben gondolkodva a legfőbb problémát a tagországok eltérő rendszerei közötti kommunikáció okozhatja. Az interoperabilitás biztosítása érdekében a folyamatos rendszerfrissítés ideiglenes megoldás lehet, de eltérö generációjú rendszerek hosszú távon nem biztosíthatják a szövetségesi törekvéseket.

\section{A DINAMIKUS ÉS ELLENÁLLÓ KÉPESSÉG}

A dinamikusan változó és komplex müveleti környezetből adódó kihívások megkövetelik a dinamikus és ellenálló képességek kialakítását. Dinamikus lehet szervezeti struktúra kialakítása, ellátási lánc és a vezetés-irányítási rendszer döntéshozatali mechanizmusa is. Bár a döntés meghozatala emberi tevékenység, a döntési folyamat gyorsítható a technológia által. A James Madison Egyetem hallgatói ${ }^{16}$ kutatási eredményeik alapján megállapították, hogy a döntéshozók sokszor azért halogatják a döntést, mert további információra vagy megerősítésre várnak, ami a katonai erő gyors telepítésére legnagyobb befolyással bíró elem. A probléma megoldása érdekében számítógépes applikációt ${ }^{17}$ terveztek, melynek alkalmazásával felgyorsítható az időkényszer alatti döntéshozatal.

A katonai erők telepítésük során jelentős mértékben a polgári szféra támogatására vannak utalva, különösen a közlekedési infrastruktúrák és eszközök, az infokommunikációs és az energiaellátó rendszerek vonatkozásában, de említhetjük még az élelmiszer- és ivóvízellátást is. A BNT-infrastruktúra vonatkozásában a közlekedési és ellátási útvonalak, állandó vagy ideiglenes bázisok, a logisztikai ellátórendszer védelme, a fizikai biztonság és a hozzáférés ellenőrzése alapvető feltétel.

Természeti vagy akár az ember okozta katasztrófák elterjedése miatt - esetleges hibrid hadviselés hatásának csökkentése érdekében - a nemzeti ellenálló képesség magas szintje különösen fontossá válik. A katonai és a polgári képességek összehangolása nélkül a rombolt infrastruktúra helyreállítása hosszadalmas, ami a katonai müveletek sikeres végrehajtását is akadályozza. Mindez megköveteli a kormányzati és a nem kormányzati szervek, valamint a gazdasági szereplők bevonását a tervezésbe és közös gyakorlatok végrehajtásába.

15 Vauver Viktor: A NATO müveleti logisztikai lánc menedzsment II. Katonai Logisztika, 2012/1., 19-31. http://epa.oszk.hu/02700/02735/00071/pdf/EPA02735_katonai_logisztika_2012_1_019-031.pdf (Letöltés időpontja: 2020. 03.31.)

16 Eric Gorton: NATO invites students to present project. 26. 03. 2019. https://www.jmu.edu/news/2019/03/22-nato-students.shtml (Letöltés időpontja: 2020. 01. 18.)

${ }^{17}$ Decision Forcing Exercise (DFE). https://sites.lib.jmu.edu/hacking-for-diplomacy-fall-2018/teams/first-act/ the-product/ (Letöltés időpontja: 2020. 01. 18.) 
A támogatórendszer túlélési képességének fokozása érdekében csökkenteni kell a logisztikai rendszer ökológiai lábnyomát, fejleszteni az elosztóhálózat dinamikáját és mobilitását. Jelen esetben a dinamizmus növelése a statikus készletek csökkentését jelenti.

Az AutoStore ${ }^{18}$ norvég fejlesztésü robotizált raktárban az eddigieknél jobb helykihasználás és hihetetlen kiszolgálási gyorsaság érhetö el. Egy $3000 \mathrm{~m}^{2}$-es modulban 65 robot 80 ezer tárolórekeszt mozgat, a 15 kibocsátókapu teljesítménye 7000 rendelési sor óránként. Egy magyar fejlesztés összecsukható konténerei a merev vázas konténerhez képest közel 80\%-os logisztikai költségcsökkentést érnek el, mivel egy kamion hagyományos üres konténerből csak két darabot, összecsukhatóból viszont 10 darabot is képes egyszerre szállítani. A védelmi piacra fejlesztett konténerekhez környezetbarát vizesblokkok, napelemes energiaellátás, golyó- és repeszálló panelekkel kialakított rendszerek is kapcsolhatók. A konténer használható átmeneti infrastruktúraként katasztrófahelyzetben és hadgyakorlatokon is, de robotizálva telepíthető autonóm raktárként is üzemelhet. ${ }^{19}$

\section{ALTERNATÍV ENERGIÁS MEGOLDÁSOK}

Az alternatív energiák alkalmazásának célja a polgári életben alapvetően a költségek csökkentésével elérhető versenyelőny, illetve a társadalmi szerepvállalás. Katonai szemszögből nézve az energiahatékonyság növelésének harcászati hozadéka is van, a hatékonyság mellett a hatásosság is nőhet.

A NATO Észak-atlanti Tanács a brüsszeli csúcsot követő nyilatkozatában ${ }^{20}$ elköteleződött a szövetséges haderő energiahatékonyságának fenntartható energiaforrások alkalmazásával történő növelése mellett. Jóllehet a nyilatkozat a 2019. év terméke, a NATO a megújuló energia és fejlett energiamenedzsment alkalmazása érdekében már 2011-ben elindította Smart Energy programját, melynek keretében - a hazánkban megrendezett Capable Logistician 2015 gyakorlaton - 50 eszközt teszteltek. ${ }^{21}$ Bemutattak tábori energiaellátást biztosító, szél- és napenergiát hasznosító eszközöket, valamint szigetelőanyagokat, alacsony energiafelhasználású technológiákat és hordozható üzemanyagcellát is. ${ }^{22}$ A hosszú távú cél az üzemanyag-fogyasztást csökkentő technológiák létrehozása.

Azonnali megtakarítás érhető el a hibrid generátorok alkalmazásával, melyek amellett, hogy akár 50\%-kal is csökkenthetik az üzemanyag-felhasználást, ${ }^{23}$ élettartamuk hosszabb,

18 Több száz kiállító várja a látogatókat az Autonet Mobility Shown. https://www.szatmar.ro/Tobb_szaz_kiallito_varja_a_latogatokat_a_Autonet_Mobility_Shown/hirek/91549 (Letöltés időpontja: 2020. 01. 18.)

19 Összecsukható konténerekkel lép az izraeli védelmi piacra egy magyar startup. 2020. 01. 16. https://hungarokamion.hu/2020/01/16/osszecsukhato-kontenerekkel-lep-az-izraeli-vedelmi-piacra-egy-magyar-startup/ (Letöltés időpontja: 2020. 03. 31.)

${ }^{20}$ Brussels Summit Declaration - Issued by the Heads of State and Government participating in the meeting of the North Atlantic Council in Brussels 11-12 July 2018., para 78. NATO E-library, 11. 07. 2018. https:/www.nato. int/cps/en/natohq/official_texts_156624.htm (Letöltés időpontja: 2020. 01. 16.)

${ }^{21}$ NATO „Smart Energy” exercise gets underway in Hungary. NATO E-library, 08. 06. 2015. https://www.nato.int/ cps/en/natohq/news_120481.htm (Letöltés időpontja: 2020. 01. 16.)

22 NATO SMART ENERGY CAPABLE LOGISTICIAN 2015 - 8-19 June 2015 HUNGARY. 08. 08. 2017. https://www.nato.int/nato_static_fl2014/assets/pdf/pdf_2017_08/20170808_Smart-Energy-Ex-Capable-Logistician2015.pdf (Letöltés időpontja: 2020. 01. 16.)

${ }^{23}$ Martin LaMonica: Hybrid Generator Would Cut Military Base Fuel Costs in Half. 03. 02. 2014. https://spectrum. ieee.org/energywise/aerospace/military/hybrid-generator-would-cut-military-base-fuel-costs-in-half (Letöltés idöpontja: 2020. 01. 16.) 
ráadásul megbízhatóbbak. Jóllehet drágábbak a jelenlegi rendszereknél, hamar megtérülő befektetésnek bizonyulhatnak.

A konvencionális üzemanyagoktól való függés csökkentését vagy megszüntetését teszik lehetővé a hibrid-elektromos és hidrogénüzemanyag-cellás jármüvek. ${ }^{24} \mathrm{Az}$ energiatárolási technológiák rohamos fejlődése, az akkumulátorok kapacitásának és élettartamának növekedése következtében a katonai alkalmazás kutatása is felgyorsult. A hibrid meghajtás nagyobb nyomatékot, ezáltal jobb gyorsulást eredményez - akár néma csendben -, ami kétségtelen harcászati előny. Másrészt, a nagy kapacitású akkumulátor lehetővé teszi a fedélzeti rendszerek üzemeltetését a dízelhajtómű beindítása, vagyis motorzaj, füst- és hőkibocsátás nélkül. Hidrogénüzemanyag-cella alkalmazásával akár 100 kW energia, 640 km hatótávolság is elérhető, mindezek mellett a hajtómü óránként 7 liter vizet termel, ami vegytisztítást követően ihatóvá válik.

A magyar hidrogéngazdaság kiemelt területe a hazai klímastratégiai célok megvalósításának. Az alternatív, hidrogénhajtású közlekedés fejlesztése eredményeként mutatták be hazánkban a világ első hidrogénüzemanyag-cella meghajtású, személyszállításra is alkalmassá tehető, magyar-amerikai együttmüködésben fejlesztett légi jármüvét. ${ }^{25}$ Mivel a hidrogéncella hosszabb üzemidőt tesz lehetővé, az eszköz alkalmazása a logisztikai disztribúciós hálózatban vagy a harctéri sérültek kiürítésében nagyobb távolságokban is tervezhető.

\section{ÖSSZEFOGLALÁS}

A megváltozott környezetben csak új elvek mentén kialakított képességekkel érhető el a logisztikai rendszer dinamikusságának, reagálóképességének és túlélőképességének fejlesztése. A modern katonai müveletek egyre komplexebbekké válnak, ezért a csapatok egyre nagyobb dinamizmusára és ellenálló képességére van szükség a müveleti előny megszerzése érdekében. Ennek eszköze lehet a logisztika is, amennyiben partnerként, és nem kizárólag ellátófunkcióként tekintünk rá, amely a beszerzéseket koordinálja.

A legfontosabb cél olyan logisztikai vezetési és irányítási struktúra kialakítása, amely védett a kibertámadások ellen, fejlett elemzőképességgel, valamint harcászati, hadmüveleti és stratégiai szinteken átívelő információs rendszerrel rendelkezik. A hatékony információs rendszerek fejlesztésével elérhető az információs fölény, a döntéstámogató funkciók gyorsítják a döntéshozatalt.

A logisztika sikere alapvetően harcászati szinten kézzelfogható, vagyis a megfelelő erőforrás kerül a megfelelő helyre és időben. A hadmüveleti szinten elért siker érdekében integrálni kell a müveletben részt vevő - logisztikai képességeket nyújtó - valamennyi szereplőt: szövetséges partnereket, kormányzati és nem kormányzati szerveket, szolgáltatókat, ideértve a BNT-rendszer elemeit is, így biztosítva a harcászati és a stratégiai szintek közötti kapcsolódást.

A jövőben a részvétel az országvédelemben és az expedíciós müveletekben egyaránt hangsúlyossá válik. A gyorsan változó müveleti környezet és tempó miatt valamennyi erö-

\footnotetext{
${ }^{24}$ Yasmin Tadjdeh: Army Driving Forward with Electric Vehicle Plans. National Defense, 21. 02. 2019. https://www.nationaldefensemagazine.org/articles/2019/2/21/army-driving-forward-with-electric-vehicle-plans (Letöltés időpontja: 2020. 01. 16.)

${ }^{25}$ Világszintű találmány Magyarországon, hidrogénhajtású repülő. 2020. 01. 22. https://www.portfolio.hu/uzlet/20200122/vilagszintu-talalmany-magyarorszagon-hidrogenhajtasu-repulo-413295 (Letöltés időpontja: 2020. 01. 22.)
} 
forrás és képesség azonosítását és követhetőségét biztosítani kell. Az információs rendszerek és adatbázisok integrálása mellett elengedhetetlen a teljesítmény mérése, ami a folyamatok további racionalizálását, finomhangolását biztosítja.

Az energiahatékonyság növelésének harcászati hozadéka van, elsősorban a gyorsan megtérülő, illetve a magyar gazdaságot támogató technológiák vizsgálata javasolt.

A képességfejlesztés nem egy végrehajtandó feladat, hanem a környezet változásaihoz igazodó hosszú távú folyamat. Hiába ismerjük a legmodernebb technológiát, a haderőfejlesztésnek nem a jelen, hanem a jövő kihívásainak kell megfelelni, mivel a folyamatok évekig tartanak. A közeljövő logisztikai műveleteit a jelenlegi rendszerekhez illesztett új, innovatív technológiák határozzák meg, a képességeket modulárisan, a magas intenzitású müveletek támogatási követelményeinek megfelelve kell megtervezni és kialakítani.

\section{FELHASZNÁLT IRODALOM}

A Cisco szerint ezek lesznek a legjellemzőbb trendek a következő évtizedben. 2019. 12. 30. http:// androgeek.hu/hir/a-cisco-szerint-ezek-lesznek-a-legjellemzobb-trendek-a-kovetkezo-evtizedben

Artificial intelligence in logistics - A collaborative report by DHL and IBM on implications and use cases for the logistics industry. 2018. https:/www.ibm.com/downloads/cas/XOQW7Q0D

Brussels Summit Declaration - Issued by the Heads of State and Government participating in the meeting of the North Atlantic Council in Brussels 11-12 July 2018. NATO E-library, 11. 07. 2018. https://www.nato.int/cps/en/natohq/official_texts_156624.htm

Constantini, Claudio: How the US Army Views the Role of AI in Future Military Warfare. 18. 01. 2019. https://www.linkedin.com/pulse/how-us-army-views-role-ai-future-military-warfare-claudio-costantini/

Decision Forcing Exercise (DFE). https://sites.lib.jmu.edu/hacking-for-diplomacy-fall-2018/teams/ first-act/the-product/

Federated Mission Network. https://dnbl.ncia.nato.int/FMNPublic/SitePages/Home.aspx

Framework for Future Alliance Operations. Allied Command Transformation, Norfolk, 2018. https:// www.act.nato.int/images/stories/media/doclibrary/180514_ffao18-txt.pdf

Gorton, Eric: NATO invites students to present project. 26. 03. 2019. https://www.jmu.edu/ news/2019/03/22-nato-students.shtml

Jároscsák Miklós: Katonai logisztika gyakorlata - Attekintés a befogadó nemzeti támogatás katonai logisztikát érintő igényeiről. Katonai Logisztika, 2003/1., 164-189. http://epa.oszk. hu/02700/02735/00044/pdf/EPA02735_katonai_logisztika_2003_1.pdf

LaMonica, Martin: Hybrid Generator Would Cut Military Base Fuel Costs in Half. 03. 02. 2014. https:/spectrum.ieee.org/energywise/aerospace/military/hybrid-generator-would-cut-militarybase-fuel-costs-in-half

Magyarország Nemzeti Katonai Stratégiája, 2012. https://www.kormany.hu/download/a/40/00000/ nemzeti_katonai_strategia.pdf

NATO Agency supports Exercise Steadfast Cobalt 2019. NCI Agency, 27. 07. 2019. https://www.ncia. nato.int/NewsRoom/Pages/20190726-NATO-Agency-supports-Exercise-Steadfast-Cobalt-2019. aspx

NATO SMART ENERGY CAPABLE LOGISTICIAN 2015 - 8-19 June 2015 HUNGARY. 08. 08. 2017. https://www.nato.int/nato_static_fl2014/assets/pdf/pdf_2017_08/20170808_Smart-Energy-Ex-Capable-Logistician2015.pdf 
NATO „Smart Energy” exercise gets underway in Hungary. NATO E-library, 08. 06. 2015. https:// www.nato.int/cps/en/natohq/news_120481.htm

Összecsukható konténerekkel lép az izraeli védelmi piacra egy magyar startup. 2020. 01. 16. https:// hungarokamion.hu/2020/01/16/osszecsukhato-kontenerekkel-lep-az-izraeli-vedelmi-piacra-egy-magyar-startup/

Porkoláb Imre - Négyesi Imre: A mesterséges intelligencia alkalmazásának kutatása a haderőben. Honvédségi Szemle, 2019/5., 3-19. https://honvedelem.hu/wp-content/uploads/2019/09/HSz2019-5_03-20_Porkol\%C3\%A1b-Imre_A-mesters\%C3\%A9ges-intelligencia.pdf

Strategic Foresight Analysis 2017 Report. Allied Command Transformation, Norfolk, 2017. https:// www.act.nato.int/images/stories/media/doclibrary/171004_sfa_2017_report_hr.pdf

Tadjdeh, Yasmin: Army Driving Forward with Electric Vehicle Plans. National Defense, 21. 02. 2019. https://www.nationaldefensemagazine.org/articles/2019/2/21/army-driving-forward-with-electric-vehicle-plans

The 4 Characteristics of Big Data. 12. 03. 2019. https://www.bigdataframework.org/four-vs-of-bigdata/

Több száz kiállító várja a látogatókat az Autonet Mobility Shown. https://www.szatmar.ro/Tobb_szaz_ kiallito_varja_a_latogatokat_a_Autonet_Mobility_Shown/hirek/91549

Vauver Viktor: A NATO müveleti logisztikai lánc menedzsment II. Katonai Logisztika, 2012/1., 19-31. http://epa.oszk.hu/02700/02735/00071/pdf/EPA02735_katonai_logisztika_2012_1_019-031.pdf

Világszintü találmány Magyarországon, hidrogénhajtású repülö. 2020. 01. 22. https://www.portfolio. hu/uzlet/20200122/vilagszintu-talalmany-magyarorszagon-hidrogenhajtasu-repulo-413295 